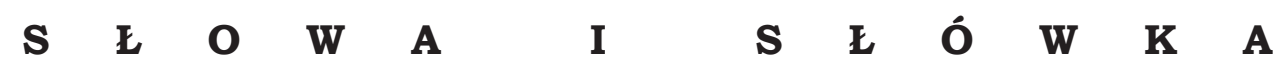

DOI: 10.33896/PorJ.2021.1.9

\title{
POŚWIĄTECZNIE O DUDKACH, DUDACH, GAJDACH I CYMBAEACH
}

Jedna ze znanych kolęd-pastorałek zaczyna się od następującej zwrotki:

Jam jest dudka Jezusa mojego,

Będę mu grał $z$ serca uprzejmego.

Graj dudka graj. Graj Panu graj.

W słownikach polszczyzny wyraz dudka jest definiowany jako 'stary (najstarszy) instrument ludowy; piszczałka, fujarka' i takie znaczenie nasuwa się $\mathrm{w}$ pierwszej kolejności w odniesieniu do zacytowanego fragmentu pastorałki. Na przeszkodzie takiej interpretacji staje jednak 1. os. lp. r.m. czasownika grać użyta w drugim wersie tego fragmentu w złożonej formie czasu przyszłego: Będę mu grał z serca uprzejmego..., trzeba zatem przyjąć, że w tym wypadku chodzi nie o te dudkę r.ż. 'piszczałkę, fujarkę', lecz o tego dudkę r.m. 'grającego na piszczałce, fujarce'. Nie ulega wątpliwości, że znaczenie pierwotne i podstawowe to 'instrument', a znaczenie 'grajacy na instrumencie' jest wtórne jako wynik jego przeniesienia (derywacji semantycznej) na określenie wykonawcy czynności. Nie ma w tym nic nadzwyczajnego w tekście o proweniencji ludowej, a znajduje to potwierdzenie w innych ludowych nazwach instrumentów takich jak duda, gajda, które w wyniku metafory również moga oznaczać grajacych na tych instrumentach, tzn. dudarza i gajdarza.

Nota bene w tekście tejże pastorałki jest również mowa o samym instrumencie określanym formą deminutywna 2. stopnia, a i powtarzający się w refrenie wyraz dudka można pod względem znaczenia interpretować dwojako:

Zagramci mu najpierwej w dudeczki,

Wy z nim chyżo skaczcie panieneczki.

Graj dudka graj. Graj Panu graj.

Sama forma dudka to słowotwórczo deminutywum od duda, które jako podstawowe ma znaczenie 'ludowy instrument muzyczny, składający się z mieszka skórzanego, zawierającego zapas powietrza, i $z$ dwóch piszczałek, $z$ których jedna służy do wygrywania melodii, druga zaś daje stały przeciagły dźwięk akompaniujący melodii; gajda, koza'. Trzeba podkreślić, że formy duda, gajda w tym znaczeniu sa już przestarzałe i słowniki polszczyzny współczesnej notuja tu już 
tylko plurale tantum $d u d y$, gajdy [zob. USJP], ale Słownik języka polskiego pod redakcja Witolda Doroszewskiego [SJPDor] w połowie XX w. jeszcze jako podstawowe podawał w tym znaczeniu formy liczby pojedynczej (duda, gajda).

Etymologicznie wyraz duda ma genezę prasłowiańską, jego podstawa jest czasownik *dudati / *duděti 'wydawać niski głos; grać na instrumencie wydajacym taki głos; grać na piszczałce’, który zapewne pochodzi od onomatopei ${ }^{*} d u-d u$ ! - por. dudnić [zob. BSEJP, SSEJP]. Zgodnie z geneza jest to określenie mające pierwotnie ogólnosłowiański i ogólnopolski zakres występowania. Synonimiczna de facto nazwa gajda ma historycznie inna genezę i inny zasięg. Jest to zapożyczenie $z$ tur.osm. gajda 'duda', które do polszczyzny przedostało się za pośrednictwem rumuńsko-mołdawskim (gaidă) wraz z osadnictwem pasterskim, posuwającym się wzdłuż Karpat ze wschodu na zachód (stąd też ukr. gajda, słowac. gajdy, czes. kejdy) zapewne w XIV-XV w. (wyraz notowany w tekstach od XVI w.) [por. SSEJP, BESJP].

Oba wyrazy - duda, gajda - jako nazwy „wdzięcznych” instrumentów zostały w polszczyźnie upowszechnione, czego wyznacznikiem sa m.in. derywaty semantyczne, dla których stały się one podstawą. Jak już zaznaczono, niejako w pierwszej kolejności zyskały one wtórne znaczenie 'muzyk grajacy na tym instrumencie; dudarz, gajdarz', co potwierdzaja notacje w Słowniku języka polskiego Samuela Bogumiła Lindego [SJPL]:

Skrzypkowie, cymbalistowie, dudowie, i insza wiejska muzyka.

W tym grobie duda leży; dudy naleziono

A po śmierci na starej wierzbie obieszono;

Smierć trochę uprzedziła, i opak się stało,

Bo co się dudom dzieje, to dudzie być miało.

Lutnista grać nie zacznie, aż gajda umilknie.

Zły gajda dobrym kornetystą nie będzie.

Dalszy rozwój obu nazw nastapił w dwóch kierunkach. Z jednej strony stały się one nazwami własnymi, przydomkami, a następnie nazwiskami. Proces ten zachodził stopniowo w okresie od XIV do XIX w. i miał charakter melioracyjny, ponieważ jako nazwiska wyrazy te uzyskiwały drugi, wyższy społecznie status językowy. $Z$ drugiej zaś - obie nazwy zyskały znaczenia pejoratywne, przezwiskowe: duda - 'głupiec, niedołęga, fujara, kiep, cymbał' [SJPDor]; gajda - 'niezgrabny, słaby, głupi człowiek’ [SSEJP]. W tym wypadku można mówić o procesie degradacji stylistyczno-znaczeniowej.

Kasztelan, duda jak zawsze, najniższy sługa jejmości, jejmość tak postanowiła, więc i on za tym [SJPDor - Zygmunt Kaczkowski].

Jest tu Francuz (...) który Anhellego zabrał się tłumaczyć; trzeba, abyśmy go uprzedzili, albowiem duda jest [SJPDor - Juliusz Słowacki].

Owa degradacja stylistyczno-znaczeniowa „dudów” i „gajdów” dokonała się zapewne ze względów pozajęzykowych. Instrumenty te służyły wyłącznie do wykonywania muzyki ludowej, którą uznawano za prymitywną, prostacka, zbyt 
hałaśliwą, a zatem również i wykonawców tej muzyki uznawano za ludzi prymitywnych i głupich. W tym procesie zmian znaczeniowych odzwierciedla się stratyfikacja społeczna i kulturowa Rzeczypospolitej stanowej. Jak wiemy, muzyka i w ogóle kultura ludowa powróciła do łask „warstw oświeconych” w XX w., ale procesy specjalizacji znaczeniowej tych wyrazów były już wówczas zakończone.

Oczywiście, w cytowanej pastorałce nie znajdujemy śladów tego typu relacji obyczajowo-językowych. Wszakże ów „dudka” jest dudką Jezusa, a wszystkie instrumenty wymienione w tym tekście tworza łącznie muzykę miła uchu nowo narodzonego Zbawiciela świata:

Na piszczałce i na multaneczkach,

$\mathrm{Na}$ bandurce oraz na skrzypeczkach.

Graj dudka graj...

Na fujarze, arfie i cymbale,

$\mathrm{Na}$ organach i wdzięcznym regale.

Graj dudka graj...

W szałamaje i w klawicymbały,

Aż dzieciątku nóżki będą drgały.

Graj dudka graj...

Na puzonie, cytrze i wioli,

Niech się dziecię ucieszy do woli.

Graj dudka graj...

Na klarnetach i do lutni zmierzę,

W trąby, w kotły na wiwat uderzę.

Graj dudka graj. Graj Panu graj.

W istocie rzeczy hałas musiałby być straszliwy, gdyby $z$ wszystkich tych instrumentów wydobyto dźwięki w sposób niezharmonizowany, bo tworzą one wręcz cała orkiestrę. Spośród nich warto może jeszcze kilka słów zamieścić o nazwie cymbały ludowy instrument strunowy składający się z pudła rezonansowego i napiętych na nim poprzecznie stalowych strun różnej długości, w które uderza się drewnianymi pałeczkami' ze względu na ciekawą etymologię i zmiany znaczeniowe. Jest to prawdopodobnie tzw. zapożyczenie wędrowne - por. czes. cymbál, cimbál, śr.-w.-niem. zimbal, włos. cembalo, łac. cymbalum, grec. kýmbalon, notowane od XV w. [por. USJP, BESJP]. Forma staropolska (występująca również $\mathrm{w}$ tekście pastorałki) to cymbał, bliska fonetycznie prawdopodobnym bezpośrednim podstawom etymologicznym w języku czeskim i niemieckim.

Spośród skrzydlatych słów trzeba przytoczyć tu biblijna metaforę od słów św. Pawła stałbym sie jak miedź brzeczaca albo cymbał brzmiacy, która pośrednio konotuje wtórne metaforyczne lekceważace lub pogardliwe znaczenie wyrazu cymbał 'człowiek głupi, krzykliwy, niezaradny życiowo; gamoń, tuman' [USJP], upowszechnione już w XVIII w.:

Głupiec, zgłupiały, nie wie, co powiedzieć, jak cymbały nie dają dźwięku, aż uderzone. Jak się spotkasz z tym cymbałem. Gotów jest w łeb ci palnąc samopałem [SJPL].

Jakim też waść jest cymbałem. Nie poznać takiego ptaka [SJPDor - Wojciech Zabłocki].

Plotą bzdury, a ty je powtarzasz jak ostatni cymbał [SJPDor - Władysław Reymont]. 
Z dudami zaś wiążą się dwa przysłowia, których rozumienie znajduje motywację w dawnych realiach: dudy $w$ miech 'o ustępowaniu, dawaniu za wygrana'; niedźwiedź zdecht, dudy w miech 'o przerwaniu, zakończeniu czegoś'. W pierwszym przysłowiu mamy nawiazanie do sytuacji, gdy dudarz po zakończeniu gry owijał piszczałki w miech opróżniony z powietrza; w drugim - odniesienie do niedźwiedników przygrywających na dudach tresowanym niedźwiedziom [KSMiTK].

Co pozostało do dziś w powszechnej świadomości z otoczki kulturowej związanej $z$ nazwami omówionymi w tym szkicu? W gruncie rzeczy tylko nazwiska - Duda, Gajda - które sa neutralne znaczeniowo, zatraciły swój dawny znaczacy (przydomkowy) charakter i jeśli wywołuja emocje (i te pozytywne, i te negatywne), to ze względu na ich nosicieli, nie zaś ze względu na postać językową. W swej podstawowej funkcji nazw instrumentów - choć notowane w słownikach - dudy, dudki, dudeczki, gajdy, cymbały znane sa chyba już tylko etnografom, muzykologom, kulturoznawcom i językoznawcom. $Z$ wtórnych pejoratywnych użyć ostał się chyba tylko potoczny cymbat i erudycyjny cymbał brzmiacy. Tempus fugit.

S.D.

\section{Bibliografia - przytaczane słowniki}

BESJP - A. Bańkowski, Etymologiczny słownik języka polskiego, t. 1, Warszawa 2000.

BSEJP - W. Boryś, Słownik etymologiczny języka polskiego, Kraków 2005.

KSMiTK - W. Kopaliński, Słownik mitów i tradycji kultury, Warszawa 1985.

SJPDor - W. Doroszewski (red.), Słownik języka polskiego, t. 1, 2, Warszawa 1958, 1960.

SJPL - S.B. Linde, Słownik języka polskiego, t. 1, 2, Lwów 1854 - wyd. Warszawa 1994.

SSEJP - F. Sławski, Słownik etymologiczny języka polskiego, t. 1, Kraków 1952. USJP - S. Dubisz (red. nauk.), Uniwersalny słownik języka polskiego, t. 1, 2, Warszawa 2003. 